\title{
The Effect of Using Panicum Mombasa Hay and Millet Hay in the diet on the Production Performance of Awassi Lambs
}

\author{
Mohammed H . Fannos ${ }^{1}$, Husam H. Nafea ${ }^{1}$, Ahmed A. Al-Ani \\ ${ }^{1}$ Student, ${ }^{2}$ Prof., College of Agriculture, University of Anbar, Iraq, ${ }^{2}$ Research Scholar, \\ Office of Agricultural Researches, Ministry of Agriculture, Iraq
}

\begin{abstract}
The current study was conducted at Al- Dawar Research Station (30 km to the northeast of Ramadi district center in Anbar Governorate)/Ministry of Agriculture/Agricultural Research Organization/Department of Animal Resource Researches, and for the period from November 1, 2019, to February 1, 2020. This research aims to study the feeding role on the Panicum maximum Mombasa hay and Millet hay compared to the alfalfa hay and the mixing between them on the production traits of Awassi lambs. In this experiment, 20 heads of Awassi sheep were used, their ages ranged from 5 to 6 months, and their average weight was $37 \pm$ $0.75 \mathrm{~kg}$. The animals were distributed randomly into five treatments, each treatment containing 3 females and one male; all animals were fed (group feeding/treatment) during the experiment time on the same diet of concentrated forage provided at a percentage of $2 \%$ of live body weight/treatment/day. As for the rough forage, it was also provided daily/treatment, but freely, and the next morning the remainder of the concentrated and rough forage was weighed/group. The average total weight gain, the average daily weight gain, the average daily consumption, and the feed conversion efficiency were calculated, and it was observed that there were no significant differences between the treatments in the average live body weight, the total and daily weight gain, the amount of total feed intake (concentrated and rough) and the feed conversion efficiency. It can be concluded from this that the use of Panicum maximum Mombasa hay and Millet hay did not negatively affect the product performance of the Awassi lambs.
\end{abstract}

Keywords: Panicum Mombasa Hay, Millet Hay, Production Performance, Awassi Lambs.

\section{Introduction}

Iraqi sheep are characterized by low production due to malnutrition, weak soil programs, improvement and poor management, and among the most important reasons that lead to low livestock productivity that is considered, as one of the main problems that farmers face to increase their livestock production is the lack of available forage. One of the important ways to increase the availability of forage in Iraq is to introduce improved forage crop varieties and plant them in the appropriate areas, as there are many types of forage that have been

\section{Corresponding Author:}

\section{Dr. Husam H. Nafea}

Prof., College of Agriculture, University of Anbar, Iraq e-mail: hussam_979@yahoo.com newly introduced, including Panicum (Guinea grass). It is a plant of the Poaceae family, where its scientific name is panicum maximum and the English name is Guinea grass $^{(1)}$, which is considered a perennial herb ${ }^{(2,3)}$. However, its cultivation succeeds in tropical and subtropical regions of the world, and it has a tremendous system of roots, which makes its resistance to drought high. In addition to that, it tolerates high temperatures $\left(37-40^{\circ} \mathrm{C}\right)$; while the height of Panicum may reach three meters and is characterized by good palatability and a high yield of good quality leaves ${ }^{(4,5,6)}$. Furthermore, its production period is up to ten years, which its productivity is higher than that of alfalfa, Panicum tolerates high salinity of water and soil ${ }^{(7)}$. Other ways to increase the availability of feed include the use of improved varieties, which are characterized by high production of forage and rapid growth, and their high ability to regrow them, as they have become the focus of researchers' attention to 
cultivate and improve them ${ }^{(8)}$. Among these crops is also the millet plant (Pennesetum glaucum L.), where millet is one of the seven most important crops in the world and the second most important crop grown primarily for a dual-purpose after maize. Besides, it is a major crop in semi-arid regions of India and Africa ${ }^{(9)}$ and is from the summer crop, which is characterized by abundant growth and many branches, with its smooth, erect stem that carries a large number of leaves that have the ability to regrowth. As it is possible to obtain 3-4 cuts during the growing season, in addition to that the productivity of green forage for millet is superior to many varieties of sorghum ${ }^{(10),(11)}$ mentioned that the millet plant could play an important role as a source of forage for ruminants due to its high tolerance to droughts, its short growth cycle that ranges from 60 to 90 days, and its effective ability to regrowth. Finally, the current study aimed to identify the role of feeding on the Panicum Mombasa hay and millet hay, compared to the alfalfa hay and mixing them on the productive performance of the Awassi lambs.

\section{Materials and Method}

Animal Feeding: All the experimental animals underwent a preparatory stage for a week before the experiment starts, as all of them were fed (group feeding/ group) on concentrated forage, as shown in Tables 1 and 2 at a percentage of $2 \%$ of the total live body weight/ group, as it is provided at eight in the morning. The rough forage was provided freely as shown in Table 2, where the animals of the first treatment $\left(T_{1}\right)$ were fed on alfalfa hay, the second treatment $\left(\mathrm{T}_{2}\right)$ on Panicum hay, and the third treatment $\left(\mathrm{T}_{3}\right)$ on millet hay. Also, the fourth treatment $\left(\mathrm{T}_{4}\right)$ on $50 \%$ millet hay and $50 \%$ alfalfa hay, and the fifth treatment $\left(\mathrm{T}_{5}\right)$ on $50 \%$ Panicum hay and $50 \%$ alfalfa hay. The quantity of both concentrated and rough forage consumed daily for each treatment was calculated by weighing the amount provided and subtracting the remaining during the experiment time. While drinking water and mineral salt block were always available for all animals during the experiment. The animals were weighed weekly with an electronic balance for small ruminants to calculate the weight gain/ animal/week, in addition to adjusting the concentrated forage quantities provided to each group in light of the total live body weight/group.

Table [1] The percentages of nutrients included in the concentrated diet

\begin{tabular}{|l|c|}
\hline Nutrients & $\mathbf{\%}$ \\
\hline Barley & 40 \\
\hline Bran & 30 \\
\hline Corn & 15 \\
\hline Soybean & 12 \\
\hline Limestone & 2 \\
\hline Salt & 1 \\
\hline Total & $\mathbf{1 0 0}$ \\
\hline
\end{tabular}

Table [2] The chemical composition of the substances included in the composition of concentrate diet, alfalfa hay, Panicum hay, and millet hay

\begin{tabular}{|l|c|c|c|c|}
\hline Materials \% & Concentrate forage & Alfalfa hay & Panicum hay & Millet hay \\
\hline Moisture & 7.54 & 9.14 & 12.71 & 12.65 \\
\hline Dry matter & 95.91 & 90.14 & 96.52 & 14.44 \\
\hline Ash & 12.16 & 10.97 & 1.92 & 8.56 \\
\hline Ether extract & 4.97 & 1.62 & 20.80 & 0.97 \\
\hline Crude fiber & 7.38 & 19.96 & 16.68 & 10.59 \\
\hline Total protein & 14.97 & 15.25 & & 13.14 \\
\hline
\end{tabular}

\section{Results and Discussion}

Average Weekly Weight Gain: Table [3] showed the effect of using Panicum and millet hay on average body weights during the experiment time, as there was no significant difference between the treatments in all periods of the experiment. 
Table [3]: The effect of using Panicum hay and millet hay in the diet on average live body weight (Mean \pm standard error)

\begin{tabular}{|c|c|c|c|c|c|c|}
\hline \multirow{2}{*}{ Weeks } & \multicolumn{5}{|c|}{ Treatments } & \multirow{2}{*}{ Sig } \\
\hline & $\mathbf{T}_{1}$ & $\mathbf{T}_{2}$ & $\mathbf{T}_{3}$ & $\mathbf{T}_{4}$ & $\mathbf{T}_{5}$ & \\
\hline 1 week & $36.60 \pm 2.10$ & $39.10 \pm 2.00$ & $39.26 \pm 3.18$ & $38.13 \pm 1.77$ & $38.66 \pm 1.04$ & NS \\
\hline 3 weeks & $38.66 \pm 2.77$ & $41.20 \pm 1.85$ & $41.66 \pm 3.18$ & $40.53 \pm 2.06$ & $41.00 \pm 1.70$ & NS \\
\hline 5 weeks & $40.93 \pm 3.34$ & $43.06 \pm 1.79$ & $42.73 \pm 3.12$ & $41.60 \pm 2.41$ & $42.60 \pm 2.10$ & NS \\
\hline 7 weeks & $41.26 \pm 1.61$ & $43.53 \pm 1.47$ & $44.0 \pm 3.63$ & $43.56 \pm 2.18$ & $43.93 \pm 2.00$ & NS \\
\hline 9 weeks & $42.33 \pm 2.40$ & $45.86 \pm 0.86$ & $47.06 \pm 3.69$ & $45.66 \pm 2.64$ & $45.40 \pm 2.38$ & NS \\
\hline 11 weeks & $44.73 \pm 3.33$ & $46.46 \pm 1.15$ & $47.56 \pm 3.86$ & $46.80 \pm 3.40$ & $47.06 \pm 2.45$ & NS \\
\hline 13 weeks & $48.40 \pm 3.71$ & $50.26 \pm 0.98$ & $51.53 \pm 4.09$ & $50.93 \pm 2.97$ & $51.46 \pm 3.13$ & NS \\
\hline
\end{tabular}

Note: NS means that there are no significant differences between the treatments.

Except, it was observed from the results that the treatment $\left(\mathrm{T}_{2}\right)$ and $\left(\mathrm{T}_{3}\right)$ are arithmetically superior over the rest of treatments in the first week, and in the fifth week, the results showed an arithmetic increase in body weight in the treatment $\left(\mathrm{T}_{2}\right)$ over the other treatments. In the other weeks, it is evident from the same Table that there was an arithmetic increase in the average body weight in the treatment $\left(\mathrm{T}_{3}\right)$ over the other treatments. The results of this study are agreed with the (12) findings that they did not notice a significant difference between the treatments in the study, which included feeding goats on Panicum hay, green Panicum, Panicum hay and Panicum silage in average body weight. Besides, (13) did not notice a significant difference between the treatment which are fed Panicum and other treatments that are fed different types of forages. Whereas, the results of the study did not agree with (14) when feeding Panicum to African rams with the addition of leguminous grains, as the treatments of adding legume supplements are significantly superior $(\mathrm{P} \leq 0.05)$ in body weight over the treatment of Panicum only. Finally, (15) noted significant differences $(\mathrm{P} \leq 0.05)$ in the average body weight of goats fed on Panicum while providing cobalt in different proportions orally.

Total Weight Gain: The results of Table 4 showed the effect of using Panicum and millet hay in the diet on the average total weight gain during the experiment time. It was observed from the results that there were no significant differences between the treatments, but there is an arithmetic superiority in the treatment $\left(\mathrm{T}_{4}\right)$ and the treatment $\left(\mathrm{T}_{5}\right)$ over the other treatments. The results of the study agreed with the (16) findings in their experiment on goats, that there was no significant difference between the treatment fed on Panicum and the treatment fed on Panicum with an addition of $15 \%$ of the Moringa leaves. The results did not agree with (13) finding, in which they were observed significant differences $(\mathrm{P} \leq 0.05)$ between the treatments in the average total weight gain. As well as, (14) showed the presence of a significant difference $(\mathrm{P} \leq 0.05)$ between the treatment that fed only Panicum and the treatment that fed on Panicum with the addition of legume supplements, the treatments that were added to the legume supplements were superior.

Daily Weight Gain: It is evident from the results of Table [4] that there were no significant differences between animals in the average daily weight gain between treatments and for all periods, and the Table observed the arithmetic superiority in the treatments $\mathrm{T}_{4}$ and $\mathrm{T}_{5}$ over the other treatments. These results are consistent with the ${ }^{(17)}$ findings that showed there were no significant differences between calves fed on Panicum and calves fed on different grass, and ${ }^{(12)}$ did not observe a significant difference between the treatments of four forms of Panicum (hay, green, silage, and hay) that were fed to sheep. Moreover, the results of this study did not agree with what ${ }^{(11)}$ findings when feeding rams on the millet silage with the addition of different percentages of urea, and significant differences $(\mathrm{P} \leq 0.05)$ were observed between the treatments, as the addition treatments were superior in the daily weight gain. Furthermore, (18) showed in a study on African goats, there was a significant difference $(\mathrm{P} \leq 0.05)$ between the treatments, where the treatments fed on Panicum by adding 10 and $15 \%$ of the Moringa leaves were significantly superior $(\mathrm{P} \leq 0.05)$ to the treatment fed on Panicum only. 
Total feed intake: It is evident from the results of Table [4] that there were no significant differences between the treatments in the amount of total feed intake. However, it was observed from the Table results that there was an arithmetic increase in the amount of feed intake in the treatments $\mathrm{T}_{1}, \mathrm{~T}_{2}, \mathrm{~T}_{5}$, the results are consistent with ${ }^{(17,18)}$. These results differed with ${ }^{(14)}$ findings when they fed rams on Panicum and Panicum with the addition of legume supplements, as they found a significant difference between the treatments in the amount of feed intake. ${ }^{(19)}$ observed the presence of a significant increase in the amount of feed intake between the treatment of rams that fed on Panicum only and treatments that were fed Panicum with the addition of different proportions of cotton seeds and Moringa leaves.

Feed conversion efficiency: It is evident from the results of Table [4] that there was no significant difference between the treatments in the feed conversion efficiency, where the treatment $T_{2}$ achieved a mathematical improvement compared to other treatments. The study results agreed with (13), and with (12) that observed no significant differences in the feed conversion efficiency when feeding goats on Panicum compared to other treatments. The study results differed with the (14) findings, that showed a significant difference $(\mathrm{P} \leq 0.05)$ in the feed conversion efficiency of male African sheep, where the treatment that fed Panicum with the addition a variety of legume supplements exceeded over the treatment fed on Panicum only. ${ }^{(11)}$ study showed that there was a significant improvement $(\mathrm{P} \leq 0.05)$ in the treatment of sheep fed on the millet silage with an addition of $20 \%$ of urea in the feed conversion efficiency over the treatment fed on the millet silage without any addition.

Table [4] The effect of using Panicum hay and millet hay in the diet on the total and daily weight gain, feed consumption and feed conversion efficiency (mean \pm standard error)

\begin{tabular}{|c|c|c|c|c|}
\hline \multirow{2}{*}{ Treatments } & \multicolumn{5}{|c|}{ Studied traits } \\
\cline { 2 - 5 } & Total weight gain (kg) & Daily weight gain (g) & $\begin{array}{c}\text { Amount of feed intake (hay } \\
\text { concentrate) (kg) }\end{array}$ & $\begin{array}{c}\text { Food conversion } \\
\text { efficiency }\end{array}$ \\
\hline $\mathrm{T}_{1}$ & $11.80 \pm 1.61$ & $131.11 \pm 17.96$ & $476.64 \pm 12.36$ & $8.25 \pm 0.52$ \\
\hline $\mathrm{T}_{2}$ & $11.16 \pm 1.64$ & $124.07 \pm 18.32$ & $471.40 \pm 10.55$ & $7.90 \pm 0.39$ \\
\hline $\mathrm{T}_{3}$ & $12.26 \pm 0.96$ & $136.29 \pm 10.75$ & $462.80 \pm 10.26$ & $8.83 \pm 0.64$ \\
\hline $\mathrm{T}_{4}$ & $12.80 \pm 1.24$ & $142.22 \pm 13.87$ & $456.76 \pm 9.46$ & $9.34 \pm 0.64$ \\
\hline $\mathrm{T}_{5}$ & $12.80 \pm 2.10$ & $142.22 \pm 23.23$ & $475.75 \pm 12.52$ & $8.96 \pm 0.51$ \\
\hline Significance level & $\mathrm{NS}$ & $\mathrm{NS}$ & $\mathrm{NS}$ & $\mathrm{NS}$ \\
\hline
\end{tabular}

Note: N.S means no significant differences between the treatments

\section{Conclusion}

The study results observed the absence of significant differences between the five treatments in each of the average weekly body weight, total and daily weight gain, the total amount of forage (concentrated and roughly) intake, and the feed conversion efficiency.

\section{Conflict of Interest: None}

Funding: Self

Ethical Clearance: Not required

\section{References}

1. Muir, James P, \& Jank, L.. Guinea grass. Warmseason (C4) grasses, 2004. 45, 589-621.
2. Aganga, A. A., \& Tshwenyane, S.. Potentials of Guinea grass (Panicum maximum) as a forage crop in livestock production. Pakistan journal of nutrition, 2004. 3(1), 1-4.

3. Pedreira, B. C., Pedreira, C. G. S., \& Lara, M. A. S. Leafage, leaf blade portion, and light intensity as determinants of leaf photosynthesis in Panicum maximum Jacq. Grassland Science, 2015. 61(1), 45-49.

4. Corsi, M., \& Santos, P. M. Potencial de produção do Panicum maximum. SIMPÓSIO SOBRE MANEJO DA PASTAGEM, 1995. 12, 275-303.

5. Chen, C. P., \& Hutton, E. M. Panicum maximum Jacq. Plant Resources of South-East Asia, 1992. 4, 172-174. 
6. Muir, J P, Alage, A., Maposse, I. C., \& Gomide, J. A. Herbage characteristics as affected by the canopies of dominant trees in the savanna of southern Mozambique. Proc 19th IGC, 2001. 655656.

7. Hare, M. D., Phengphet, S., Songsiri, T., \& Sutin, N. Botanical and agronomic growth of two Panicum maximum cultivars, Mombasa and Tanzania, at varying sowing rates. Tropical Grasslands-Forrajes Tropicales, 2014. 2(3), 246-253.

8. Akash, M. W., \& Saoub, H. M. Grain yield of three sorghum varieties as influenced by seeding rate and cutting frequency. Journal of Agronomy. 2002.

9. Sridevi, N. Marker-assisted introgression of stover quality QTL in pearl millet. Acharya NG Ranga Agricultural Univerisity. 2005.

10. Shah, P., \& Perveen, S. Growth characters and productivity of forage oats varieties at Peshawar [Pakistan]. Sarhad Journal of Agriculture (Pakistan). 2004.

11. Carvalho, G. G. P., Freitas, P. M. D., Santos, E. M., Araújo, G. G. L., Oliveira, J. S., Pires, A. J. V., Maranhão, C. M. A., Rodrigues, T. C. G. C., Freitas Júnior, J. E., Rufino, L. M. A., Rodrigues, C. S., Leite, L. C., \& Araujo, M. L. G. M. L. Effect of pearl millet silage ammoniated with urea on lamb production and metabolic performance. Grass and Forage Science, 2018. 73(3), 685-693.

12. Eyoh, G. D., Udo, M. D., \& Edet, C. P. Growth Performance and Carcass Characteristics of West African Dwarf Bucks Fed Different Forms of Processed Guinea grass (Panicum Maximum). Current Agriculture Research Journal, 2019. 7(2), 254-260.

13. Eyoh, G. D., \& Ayuk, A. A. Growth performance and carcass characteristics of West African dwarf (WAD) goats fed selected forages in Akwa Ibom State. Journal of Animal Science and Veterinary Medicine, 2019. 4(2), 78-83.
14. Ojo, Victoria Olubunmi A., Oyaniran, D. K., Ogunsakin, A. O., Aderinboye, R. Y., Adelusi, O. O., \& Odusoga, F. S. Effects of supplementing herbaceous forage legume pellets on growth indices and blood profile of West African dwarf sheep fed Guinea grass. Tropical Animal Health and Production, 2019. 51(4), 867-877.

15. Yousuf, M. B., Belewu, M. A., \& Badmus, A. H. A. Effects of cobalt supplements on performance of panicum maximum hay fed goats. Centrepoint Journal, 2009. 16, 1-6.

16. Tona, G. O., Ogunbosoye, \& Bakare, B. A. Original Research Article Growth performance and nutrient digestibility of West African Dwarf goats fed graded levels of Moringa oleifera leaf meal. International Journal of Current Microbiology and Applied Sciences, 2014. 3(8), 99-106.

17. Loresco, M. M., Andal, M. J. C., Ty, K. J. S., \& Angeles, A. A. Growth Performance of Growing Dairy heifers fed fresf MULATO II (Brachiaria ruziziensis $\mathrm{x} B$. decumbens $\mathrm{x}$ B. brizantha) and MOMBASA (Panicum maximum Jacq. cv. Mombasa) Compared to NAPIER (Pennisetum purpureum Schum.). Philippine Journal of Veterinary and Animal Sciences, 2019. 45(1-3), 87-90.

18. Jiwuba, P. C., Ahamefule, F. O., Ogbuewu, I. P., \& Ikwunze, K. Blood chemistry and hematology of West African Dwarf goats fed Moringa oleifera leaf meal (MOLM) in their diet. Comparative Clinical Pathology, 2017. 26(3), 621-624.

19. Adegun, M.K., and Aye, P. A. Growth performance and economic analysis of West African Dwarf Rams fed Moringa oleifera and cottonseed cake as protein supplements to Panicum maximum Department of Animal Production and Health Sciences. American Journal of food and nutrition, 2013. 3(2), 58-63. 